\title{
Mega-Event Impact Assessment and Policy Attribution: Embedded Case Study, Social Housing, and the 2010 Winter Olympic Games
}

\author{
Caitlin Pentifallo* \& Robert VanWynsberghe \\ University of British Columbia \\ Vancouver, BC Canada \\ *corresponding author: caitlin.pentifallo@gmail.com \\ Pentifallo, C. \& VanWynsberghe, R. (2015): Mega-event impact assessment and policy \\ attribution: embedded case study, social housing, and the 2010 Winter Olympic Games, \\ Journal of Policy Research in Tourism, Leisure and Events, DOI: \\ $10.1080 / 19407963.2014 .990236$
}




\begin{abstract}
Our objective is to present a novel approach and supplement to indicator-based impact assessment through the use of embedded case study. We will build a hybridized, methodological approach in order to extend the capacity, potential, and utility of the Olympic Games Impact (OGI) study as an evaluation framework and mechanism for attribution. Assessing the impact of a sport mega-event on its host through an existing framework such as the OGI study is a complex undertaking spanning multiple indicators, variables, and scales. Yet, despite the many challenges in assessing Olympic-induced changes in host cities, we believe it is possible to use indicator-based impact assessment to aid in the formation of not only impact assessment and policy attribution, but to develop a more contextualized approach to legacy creation, monitoring, and evaluation. To test this potential, we will explore the empirical data generated through the OGI study on Vancouver 2010's social housing legacy on South East False Creek. Reconciling the quantitative information compiled by the OGI study with a more rigorous approach to qualitative, embedded case study will ideally allow for the more accurate and effective assessment of Olympic legacies and policy-making. It is our expectation that such an evaluation will prove sensitive to the political, economic, and social climate and context surrounding the hosting of the Olympic Games, and in so doing, provide added insight to the nature and formation of policy development and urban transformation in the context of an Olympic host city.
\end{abstract}

\title{
Keywords
}

Olympic Games impacts; indicator-based impact assessment; embedded case study, legacy, legacy evaluation

\section{Word count}

5,697 including footnotes

6,661 including references 
Evaluating mega-event induced impacts in Olympic host cities is no easy task. Declaratively stating the degree to which such impacts can be accurately attributed to hosting is an exceedingly difficult, if not impossible assignment. The Olympic planning period- formally a seven-year timespan between a winning bid and the opening ceremonies- often extends years or even decades prior. This effort becomes even tougher when undertaken in the context of identifying policy changes related to hosting sport mega-events (VanWynsberghe, 2014). These policies reflect the anticipation, and generally presumed acceptance, that hosting the Olympic Games will lead to an accelerated urban development trajectory, an enhanced tourist appeal, and a groundswell of investment features. The results are often murky intersections of policy and planning. In all Olympic host cities, as the initial rosy optimism of the bid phase is replaced by the imminent need to deliver on lofty, but loosely iterated, expectations of the bid, reality intervenes to establish whatever legacy remains.

One of the 2010 Games major social legacies was intended to be social housing units in the former Athletes' Village. Social housing, in Vancouver, is defined as housing for low and moderate income singles and families that is subsidized through a variety of mechanisms, such as government support (City of Vancouver, 2012). The term social housing, when applied in this context, is used synonymously with non-market housing and frequently interchanged with social housing. This effort to include social housing in the former Athletes' Village became mired in not only a global financial down turn, but also intertwined in decades-long local and provincial social housing policy debates. In reviewing how the 2010 Winter Olympic Games came to affect social housing in Vancouver, we will retrospectively reconstruct two embedded case studies of efforts to implement a social housing legacy in 2010's aftermath. Drawing upon embedded case study (Scholz, 2002), we will create a hybridized, methodological approach to extend the capacity, potential, and utility of the Olympic Games Impact (OGI) study as an evaluation framework and mechanism for policy attribution. Reconciling the quantitative information compiled by the OGI study with an equally rigorous approach to qualitative, embedded case study will ideally allow for a more accurate and effective assessment of a planned Olympic legacy while also accommodating discussion around Vancouver's political and social climate, as well as urban and provincial policies governing social housing, homelessness, and urban development.

\section{Literature Review: Mega-event Legacy and the Olympic Games Impact Study}

The study of mega-event legacy and its evaluation has barely exceeded attempts at categorization in the preceding three decades. Conflated with similarly structured terms such as impact, outcomes, and catalytic effects in both relevant literature and in practice, the area of legacy evaluation has remained somewhat stagnant despite increased attention and frequent invocation of the term. From Ritchie's (1984) division of economic, tourism/commercial, physical, socio-cultural, psychological, and political areas of impact, to Preuss's more recent (2007) division of planned and unplanned, positive and negative, tangible and intangible legacies, further attempts at clarity in matters of mega-event legacy and impact have not yielded definitive consensus on either area of discussion. 
Such uncertainty has paradoxically only served to fuel legacy's free wielding and evergrowing usage in the context of staging a mega-event, evolving into a seminal component of bid messaging and campaign rhetoric. Legacies- projected, planned, and otherwiseare routinely invoked throughout the course of bidding and preparing to stage a megaevent, not only by bid and host organizing committees, but by host governments as well. Despite a checkered history of Olympic hosts realizing such legacy commitments, megaevents such as the Olympic Games continue to be framed in terms of the value they will leave behind in host cities, even in the face of mounting expenditures and rising critique (Gold \& Gold, 2009).

Bid and host organizing committees and host governments are not the only entities promoting a legacy-centric agenda. Legacy has become central to the role and mission of the IOC, as stipulated in Rule 2, Article 14 of Olympic Charter. The IOC has declared part of its role is '... to promote a positive legacy from the Olympic Games to the host cities and host countries' (International Olympic Committee, 2004, p. 12). Legacy, as a concept, has been summarily applied to a range of initiatives spanning infrastructural upgrades, urban regeneration, and redevelopment projects, despite their actual or existing formal or financial ties to hosting the mega-event.

The formalized evaluation required by the IOC in its mandated OGI study is at least partly driven by an attempt by the world's largest sport organizing body to dispel mounting criticisms surrounding the size, cost, and questionable returns of the Games amidst rising calls for accountability (Cornelissen, 2009, pp. 88-89). The International Olympic Committee (IOC) established the OGI study in 2003 as a way of providing answers to the question: 'to what extent, with what results, and with what benefits' do the Olympic Games impact a host city and country? (International Olympic Committee, 2006, p. 1). According to an IOC factsheet, the principle objectives of OGI are:

'to measure the overall impact of the Olympic Games; to assist the bidding cities and future Olympic Games organisers through the transfer of strategic directions obtained from past and present Olympic Games; and to identify potential legacies, thereby maximizing the benefits of their Olympic Games' (International Olympic Committee, 2012, p. 3).

Since its inception, OGI studies have been executed for host cities Beijing, Vancouver, London, Sochi, and Rio de Janeiro, with Vancouver creating the first ${ }^{1}$ complete set of OGI reports. ${ }^{2}$ Typically conducted by a third-party research institution, such as a local university, OGI speaks to three spheres of potential impact- economic, environmental, and socio-cultural- through the use of indicators. ${ }^{3}$

- While Beijing completed portions of the OGI study, Vancouver represents the first Olympic host to carry out a full, or four report, study. The University of British Columbia was selected in 2007 as the third-party research arm responsible for carrying out the study, identified as the OGI-UBC Research Team.

'OGI's twelve-year reporting span (as per the 2007 Technical Manual) is punctuated by four reports: the baseline report, taking assessment two years prior to host city selection; the pre-games report, containing information from 2002-2006 and released four years prior to the start of the Games; the Games-time report, containing information from 2007-2010 and released 12 months after the Games' conclusion; and the postGames report, speaking to changes experienced in the host city three years post-Games.

Originally spanning 160 indicators and more than 30 themes, the OGI study was reduced to 126 indicators in 2006 (van Griethuysen \& Hug, 2001). This structure has undergone dramatic revision in 2011, reducing 126 indicators to 30 , and combining formerly separate indicators into larger sets of indicators. 
Yet, OGI's attempt to capture the impact of the event and generate reliable and objective inferences has yielded a massive range and scope of data collected. The OGI study calls for quantitative data in various forms of measure and proscribes its collection in terms of the timeframe for evaluation, the level of analysis, and the context in which data is situated. Indicators across all three spheres- economic, environmental, and sociocultural- contain a variety of sub-indicators, multiple scales for analysis (city, region, and country), can be reported on a monthly, annually, or for event-only basis, and can either be event-specific or context-affiliated.

While OGI was originally intended to serve as a tool for objectively assessing Games' impact on host cities, we propose to use the existing OGI structure as a basis for developing a richer, more locally meaningful mega-event evaluation framework and mechanism for policy attribution. To do this, we will revisit and expand upon the empirical data collected for Vancouver's OGI study, creating an in-depth, contextualized, embedded case study around one of the most anticipated legacies of Vancouver's 2010 Games: social housing.

\section{Methodology: Embedded Case Study and the Design of a Contextualized Approach}

The approach advocated for in this methodology section will ideally allow researchers to expand the capacity, potential, and utility of the OGI study as an evaluation framework. By utilizing an approach to embedded case study, we will demonstrate how policy development and transformation can be better understood in the context of assessing Olympic legacies and impacts.

Case study is defined as a transparadigmatic heuristic that enables circumscription of the unit of analysis by (a) providing detailed description from contextual immersion, (b) bounding the case temporally and spatially, and (c) frequent engagement between the case itself and the unit of analysis (VanWynsberghe \& Khan, 2007, p. 9). Case study calls for rigorous efforts to identify the appropriate unit of analysis amidst eminently social and often heavily contextualized settings (Heartly, 2004). Case study becomes an embedded case study when, within a single case, attention is paid to more than one subunit (Yin, 2009, p. 50). The term subunit refers to a different, salient element of the larger case (Scholz \& Tietje, 2002). Embedded design permits qualitative and quantitative data to by synthesized for the purposes of knowledge integration, incorporating multiple units of analysis within the larger case (Scholz \& Tietje, 2002).

We will assemble two embedded case studies relevant to the assessment of Vancouver 2010's social housing legacy. In each embedded case study, we will first detail the quantitative nature of the data as prescribed by each indicator before moving on to explore the ways in which broader consideration of policy contexts could be best applied to better understand the nature and effect of an attempted social housing legacy in Vancouver. First, the findings of these indicators as presented in the reports by the OGIUBC Research Team will be reviewed. This will be followed by the creation of two 
embedded case studies featuring discussion of the policies, programs, and decisionmaking that bore direct consequence and influence on social housing solidifying as an Olympic legacy. The first, on homelessness and affordable housing, will utilize data collected under the auspices of OGI indicator So31 Homeless, Low-rent Market, and Affordable Housing. Within this case study, we will expand upon subunits featuring the development of a bid phase vision for social housing as well as a subunit covering the financial arrangements and negotiations surrounding the development of the Athletes' Village. The second embedded case study will draw from data collected under OGI indicator En24 Olympic-induced housing. This case study will explore subunits related to the history and housing context within Vancouver before discussing the conversion and demolition of a key element of Vancouver's unofficial housing stock.

Figure 1. Embedded Case Studies and Subunits (adapted from Yin, 2009, p. 46)

Figure 1. Embedded Case Studies and Subunits

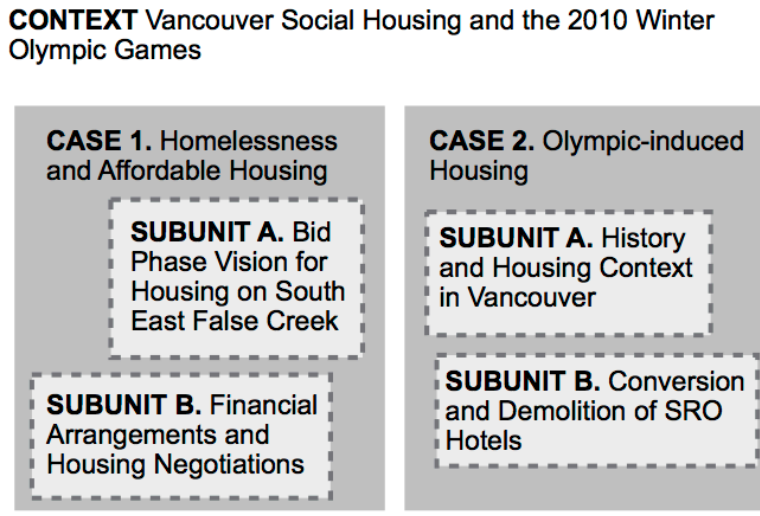

CASE 1. Homelessness and Affordable Housing

CASE 2. Olympic-induced Housing

SUBUNIT A. History and Housing Context in Vancouver

ing

SUBUNIT B. Conversion and Demolition of SRO Hotels

\section{Case Study 1: Homelessness and Affordable Housing}

The OGI indicator So31 Homeless, Low-rent Market and Affordable Housing was intended to 'monitor the situation of low rent market housing' in the host city (International Olympic Committee, 2007). The OGI-UBC reports explain the status of Vancouver's homeless population for each demographic required, which are reflected in both the Pre-Games and Games-time reports (OGI-UBC Research Team, 2011). By all available measures- such as the absolute homeless count, number of homeless persons relative to the population, and demand for shelter beds- the prevalence of homelessness and number of those already homeless or at risk of homelessness in Vancouver was expected to rise in the lead up to the 2010 Games. At the same time, the net increase of social housing units over the period 2004 to 2009 stands at 280 units while 13,400 applicants remained on the waiting list for social housing in British Columbia (OGI-UBC Research Team, 2011, pp. 73-74). These factors link directly to Vancouver's promise for a housing legacy, as a need for new units of social and affordable housing are made clear. Yet, one key feature promised by Vancouver's social housing legacy- the creation of new units in conjunction with the construction of the Athletes' Village- falls far short of meeting such needs. What the OGI study fails to assess is how the complicated financial 
relationship and negotiations surrounding the entire development of the Athletes' Village eventually jeopardized the affordable housing component of the project. Such arrangements were not only produced in conjunction with, but exacerbated by the prospect of hosting the 2010 Winter Olympic Games. In developing an embedded case study surrounding this indicator, we will explore the history of incorporating social housing into the Athletes' Village as well as the financial arrangements and housing negotiations affecting the development of social housing.

\section{Subunit A: Bid Phase Vision for Housing on South East False Creek}

Vancouver's bid organizing committee established its vision for a housing legacy in its applicant city response document: to convert the Athletes' Village in Vancouver into a mix of market and affordable ${ }^{4}$ housing' in the Games' aftermath (Vancouver Bid Corporation, 2002a, p. 5). Rationalizing the placement of the village, the document went on to explain: 'Locating the Athletes' Village in Vancouver's [Southeast] False Creek area will be a legacy and an important catalyst for completing the remediation of this former industrial site and developing a sustainable community in accordance with existing plans for the site' (p. 21). Southeast False Creek (SEFC) had been previously classified by the City of Vancouver in 1990 as an industrial property that had been 'let go' (City of Vancouver, 1999). Once a major industrial hub home to sawmills, an operational port, and the terminus of the Canadian rail system, the area containing eighty hectares of land was released from the city's industrial land base in 1990 (City of Vancouver, 1999). City Council directed that residential housing should be provided in the resulting development policy enacted for SEFC in 1991; however, it was not until Vancouver's successful Olympic bid placing the Athletes' Village at the core of the site's physical redevelopment that the project broke ground.

The bid organizing committee's vision for a 'non-market housing legacy' was solidified in the responses of the Candidature File, the official document submitted on behalf of Vancouver's bid organizing committee to the IOC as part of the host city selection process. Once described as a 'mix' of affordable housing in the Applicant File, the 'portion' of non-market housing was further specified as 250 units in the Candidature File (Vancouver Bid Corporation, 2002b, pp. 193-195). Shortly after the bid was won in 2003, the city formally integrated concepts and principles of sustainable design into the site's planning and development with the adoption of a green building strategy and the official development plans for SEFC passed in 2005 (City of Vancouver, 2004, 2005).

Provisions for a non-market housing legacy were also established in the Games Facility Agreement, which states that a portion of the permanent facilities constructed will be allocated for 'a lasting legacy to the community' (City of Vancouver, 2002, p. 11). While the city was given authority to make the 'final determination of the form and nature of the non-market housing,' it also stipulates that a 'best effort' would be made to deliver a target of 250 units of non-market housing (City of Vancouver, 2002).

- Affordable housing is defiend as 'dwelling units designed to be affordable to persons who make up a core need household where such persons pay more than $30 \%$ of their combined gross annual income to rent an adequate and suitable rental unit, including utilities, to meet the basic housing needs of the household at an average market rent' (City of Vancouver, 2005). 


\section{Subunit B: Financial Arrangements and Housing Negotiations}

The financing of the Athletes' Village project and its resulting budgetary controversies seriously jeopardized the allocation and distribution of social housing units that would remain as part of a 2010 Winter Olympic Games legacy. Vancouver's City Council became divided on 'the tension between their need to be fiscally responsible' to its taxpayers and the pre-existing commitment to providing affordable housing in the wake of the financial strains jeopardizing the project (Prosken, 2010, p. 2). Required percentages for social housing on the development site fluctuated from a minimum requirement of $20 \%$ of all units built on city owned lands in 2002 (City of Vancouver, 2006), to a household mix of $1 / 3$ affordable housing, $1 / 3$ modest ${ }^{5}$ or middle-income market housing, and 1/3 market housing in 2005 (City of Vancouver, 2005), to a requirement of $20 \%$ affordable housing plus $1 / 3$ modest market housing in 2007 (City of Vancouver, 2007b).

Table 1. Market and Affordable Rented Units.

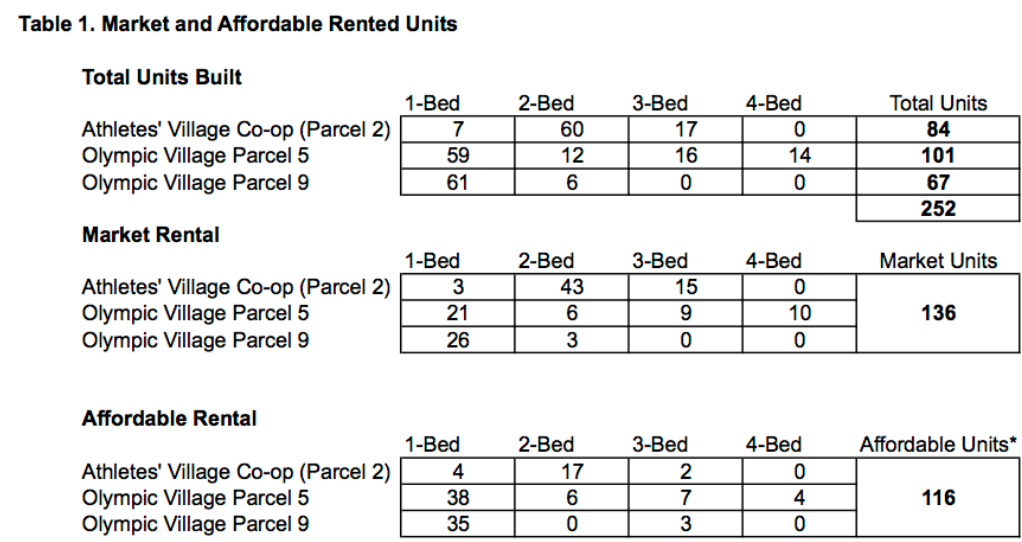

*this number includes 23 co-op rentals, which are not necessarily geared to incomes

As part of an agreement signed by the Vancouver Bid Corporation and government partners in November 2002, seven months before Vancouver was selected as the 2010 host, the City of Vancouver became responsible for the building of all permanent facilities ${ }^{6}$ at the Vancouver Athletes' Village. This was subject to a $\$ 30$ million contribution from the bid corporation, intended for the building of 250 non-market housing units (City of Vancouver, Resort Municipality of Whistler, Canadian Olympic Committee, Canadian Paralympic Committee, \& Vancouver Bid Corporation, 2002). On

\footnotetext{
${ }^{5}$ Modest market housing is explained as dwelling units designed to be affordable to those persons whose income falls within the middle third of income distribution (City of Vancouver, 2005).

${ }^{6}$ Permanent facilities are described in the Games Facility Agreement as residential accommodation, commercial space, and all permanent infrastructure including roadways, walkways, green space, power, sewer, water, and other utilities. Site preparation, geotechnical work, property leveling, and remediation also remained at the city's sole cost and risk.
} 
September 28, 2006 Vancouver City Council officially allocated VANOC's (Vancouver Organizing Committee for the 2010 Winter Olympic and Paralympic Games) \$30 million contribution for the Athletes' Village project and added an addition \$2 million for replacement housing from the development cost levies. This amount, \$32 million, was stipulated as a 'capital contribution to the 250 units of Affordable Housing to be developed in the Olympic Village' (Gray, 2006). However, the level of affordability was still unknown at this stage, as the project manager of the SEFC development and the director of the housing center were to report back on the level of affordability that could be achieved once building costs were determined (Gray, 2006).

In April 2006 Millennium Development Group was selected from an open request for proposals (RFP) (Andrews, 2006). The request required that 250 units of affordable housing be included, along with provisions made for additional modest market housing. Millennium, in its bid to become developer, promised to cover most of the costs of making the site available for development, allowing VANOC's investment to be dedicated to affordable housing accommodating core need ${ }^{7}$ households (Gray, 2006, p. 5). In order to fund Millennium, the city entered into a loan agreement with Millennium and Fortress Credit Corporation, a New York-based hedge fund, in Septebmer 2007. Key terms of the agreement included a loan facility of $\$ 750$ million from Fortress to Millennium and the subordination of the outstanding land purchase price of \$171 million owed to the City (KPMG, 2009). The city authorized this tri-party relationship between itself, Millennium and Fortress, in which the city also became a guarantor of \$190 million and provided a completion guarantee. Most crucially for the city's role in preparing the Athletes' Village for the 2010 Games, the financial arrangement meant that the city was obligated to complete the project should Millennium be unable to do so. Further, in the event of default the city would assume completion and also become responsible for the loan's repayment (Lee, 2008, p. 21).

The city's financial guarantee and role in the loan agreement would prove critical in the fall of 2008 and in the face of a global economic downturn that severely damaged the international real estate market. However, even before the global economic events of September and October 2008 the project faced budgetary concerns. In May 2008, the entire project was $\$ 35$ million over budget, and in August and September 2008 further overruns of $\$ 89$ million were identified (KPMG, 2009). Then on September 23, 2008, embattled New York-based hedge fund Fortress advised Millennium it would not provide any further funding pursuant to the original loan agreement. As $\$ 317$ million of the $\$ 750$ million loan had been advanced by Fortress to Millennium at the time progress draws 8 were halted, there was an outstanding balance of $\$ 458$ million that would be required to finish building the Athletes' Village. ${ }^{9}$ In an in-camera council session on October 14, 2008, Vancouver City Council authorized the city manager to make three protective

\footnotetext{
A core need household is one where persons pay more than $30 \%$ of their combined gross annual income to rent an adequate and suitable rental unit (City of Vancouver, 2005b).

${ }^{*}$ Progress draws of $\$ 26.6$ million were issued on a monthly basis to the wide variety of contractors working on the project; Fortress refused to make further progress draws on September 15, 2008 (Andrews, 2008).

- The city manager illustrated the budgetary issues as follows: Millennium contributed \$29 million and \$171 million (developer's deposit and land purchase balance totally $\$ 200$ million); $\$ 317$ million provided by the lender, Fortress; $\$ 100$ million provided by the city in the form of protective advances from September 2008January 2009 (Ballem, 2009).
} 
advances of up to $\$ 100$ million to Millennium. The project's original budget grew from $\$ 950$ to $\$ 1,075$ million due to what the city manager labeled as 'cost escalation/time frame contingencies' in a presentation to city council (Ballem, 2009).

On January 17, 2009 unprecedented legislation amending the Vancouver city charter to authorize council to borrow was passed. Previously under the city's charter, such extensive borrowing must first be agreed to in the form of a public referendum (CBC News, 2009; Kines \& Bermingham, 2009). The amendment to the Vancouver Charter 'provides access to a range of financial tools to ensure that the City's commitment to complete the village can be achieved and that the city's financial risks are mitigated' (Bayne, 2009, p. 3). The next day, the provincial legislature of British Columbia passed Bill 47 in an emergency all-night session, allowing Vancouver to borrow \$458 million to ensure the Village was built to completion. Council formally bought out the entire loan for \$319 million on February 18, 2009 (Ballem, Bayne, \& Philpotts, 2009).

The number of affordable housing units eventually settled on 252, the number of units contained within three free-standing buildings in the village development, but that number was halved merely one month after the games ended (Gray \& Smith, 2009). The remaining 126 units were further divided, with half going to a non-profit operator with the stipulation that those units would be dedicated to core need households. The remaining sixty-three units were allocated to households 'paying market rents which reflects the design, size, and location of the units,' having a household income of up to five times the market rent (Prosken, 2010, p. 1). An annual income five times the market rent value, $\$ 1,601$ per month for a one bedroom, is nearly $\$ 30,000$ more than the median income for Metro Vancouver. ${ }^{10}$ In the city's most recent report on the status of the Athlete's village, nearly $90 \%$ of the units are market rental, while ninety-three can be considered affordable housing. Of those units, twenty-eight or $2.5 \%$ of the total village development, are occupied by those in deep-core need and rented at the shelter assistance rate of $\$ 375$ per month (Ballem, 2011).

${ }^{10}$ The median household income for metropolitan Vancouver in 2010 was $\$ 67,090$ (Statistics Canada, 2013) while the application for tenancy permits tenants to have a maximum monthly income of $\$ 8,005$ per month, or \$96,060 annually (COHO Property Management, 2011). 
Table 2. Housing Unit Breakdown, 2005-2010.

Table 2. Housing Unit Breakdown, 2005-2010

\begin{tabular}{|c|c|c|c|c|c|}
\hline Year & 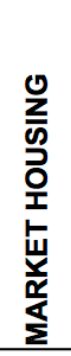 & 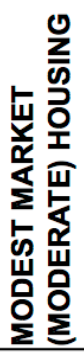 & 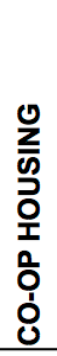 & 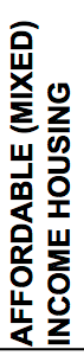 & 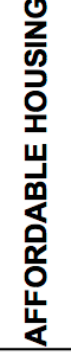 \\
\hline 2005 & 367 & 367 & & & 366 \\
\hline 2006 & 513 & 367 & & & 220 \\
\hline 2006 & 750 & 100 & & & 250 \\
\hline 2007 & 880 & & & & 220 \\
\hline 2009 & 848 & & & & 252 \\
\hline 2010 & 848 & 126 & & 126 & \\
\hline 20 & 984 & & 23 & 65 & $28^{*}$ \\
\hline
\end{tabular}

*Shortly after the 2010 Games ended, City council voted to make $50 \%$ available to core need households, thus representing the split in 2010 into mixed income affordable housing and affordable housing (Prosken, 2010). One year later, the number of units actually tied to income rose to 93 units, yet only 28 were filled by individuals paying the shelter assistance rate of $\$ 375$ per month.

Figure 2. Housing Unit Breakdown, 2005-2010.

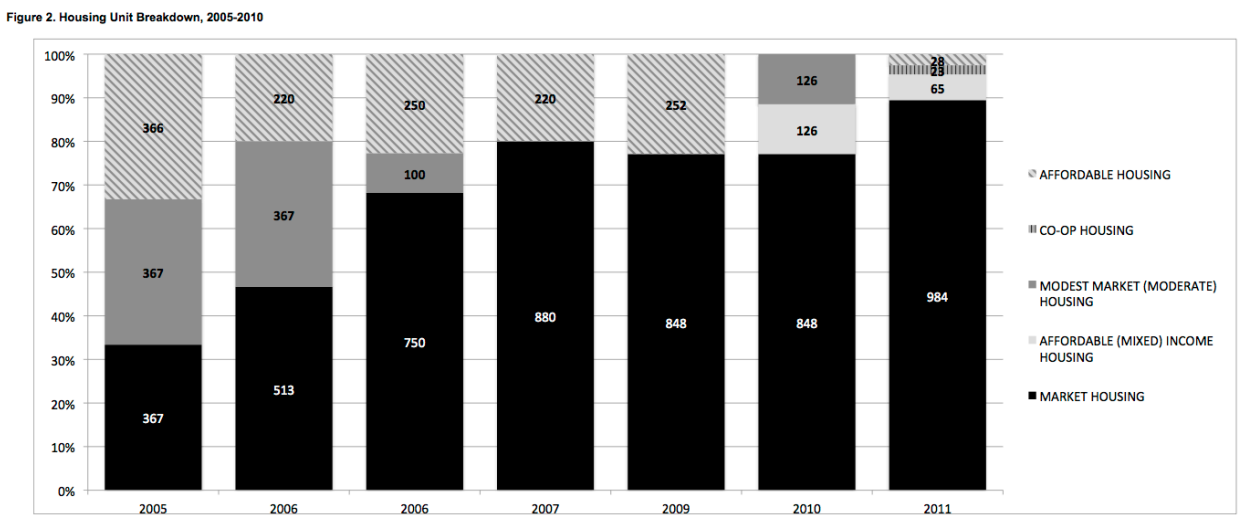




\section{Case Study 2: Olympic-induced Housing}

OGI indicator En24 Olympic-induced Housing was intended to show the net increase in housing related to hosting the Olympic and Paralympic Games. In terms of calculation and measurement, the OGI study calls for net area to be calculated in terms of residential areas newly built for the Games, minus residential area destructed for Olympic venues or context activities (International Olympic Committee, 2007, p. 90). The OGI study reports explain the total square metres of housing built for the 2010 Olympic Games: $130,064.256 \mathrm{~m}^{2}$ (OGI-UBC Research Team, 2011, p. 150). This number was accurately calculated using the City of Vancouver's Official Development Plan for South East False Creek. However, what is conspicuously absent is an accurate calculation of residential areas destructed in affiliated, context-related activities.

The OGI study notes that the available data for the Vancouver Olympic Village 'suggest[s] that a housing legacy (in terms of increased floor area) was established' (OGIUBC Research Team, 2011, p. 150). This calculation is based largely on the notion that no housing areas were destructed at the site of the Vancouver Olympic Athletes' Village, as it was a non-residential former industrial site. In order to understand the history and political context of housing at risk because of, or potentially lost as a result of, the Olympic Games, what is crucial to add to this case study is Vancouver's previous experience with mega-event related eviction and displacement. Further, the findings of this indicator will also be supplemented by the examination of a series of bylaws enacted to protect low-income housing, particularly single room occupancy (SRO) hotels, in the period immediately following Vancouver's successful Olympic bid. In addition, it is also crucial to examine how new units of housing were accounted for and the ways in which VANOC and the City of Vancouver reported on such progress towards the creation of a social housing legacy.

\section{Subunit A: History and Housing Context in Vancouver}

SROs have long been recognized as an unofficial, but crucial part of Vancouver's housing spectrum, providing a critical form of housing for low-income residents. As stipulated by the City of Vancouver in a 2007 report on DTES housing stock, SROs provide 'the lowest cost rental units in the city' and 'very little other market housing is available in the same price range' (Raynor \& Johnson, 2007, p. 3). SROs are typically ten by ten feet with shared bathrooms and usually owned and managed either privately or through non-profit housing organizations (Eby \& Misura, 2006). Also typical of SROs in the DTES are substandard living conditions; SROs are typically unsafe, unclean, in a state of disrepair, and highly inadequate for providing a standard of living (Housing Justice Project, 2012). Despite these conditions, monthly rent is usually higher than the shelter assistance component of income assistance. A 2011 report surveying private owned SRO units in the DTES found that only seven percent of units were rented at the shelter assistance rate of $\$ 375$ per month, which is a significant decline from twelve percent in 2010 and twentynine percent in 2009 (Drury \& Swanson, 2011).

Olds' research $(1988,1998)$ helps to explain the policy context in Vancouver's housing sector precipitating the loss and conversion of SRO units as well as evictions in the years 
preceding Expo '86, formally known as the World Exposition on Transportation and Communication. Attempts to prevent evictions through legislation were thwarted by a refusal to act by the provincial and city governments, both of whom did not support community organizations' assertion that SRO units in the DTES were at risk. In particular, a motion proposing a 'time limited, no-rent increase, no-eviction legislation applied to long-term residents' put forward by the Downtown Eastside Residents Association and Social Planning Department failed to pass, instead facing firm opposition (Olds, 1998, p. 10).

An interim report generated as part of the social impact assessment conducted in the bid phase for the 2010 Olympic Games alluded to the potential for negative housing impacts experienced in the city as a result of Expo '86 (Ference Weicker \& Company, 2002). Formally requested by city council in March 2002, the assessment was completed in two phases and intended to coincide with the timing and release of Vancouver's Olympic bid (Rogers, 2002). This interim report represents the concerns of DTES residents and supported the opposition's argument that the Games would adversely impact an already vulnerable sub-population living in SROs. According to the report, an estimated 1,000 to 2,000 units were demolished or closed between 1978 and 1984 and an additional 600 units were lost between 1984 and 1986, with many of these losses attributed to Expo '86 (Ference Weicker \& Company, 2002). According to Olds' (1998) research on the impact on the housing supply on Vancouver's inner-city, between 500 and 900 evictions occurred in the DTES due to pre-Expo demand and an estimated 1000 to 1500 lodging house rooms were switched from monthly rentals to tourist rental status in the months preceding Expo '86. Analysis of post-event impacts revealed that in the three years following the event, approximately 1,150 units were lost (Olds, 1998). As a response to mitigate projected housing impacts, the interim report recommended several actions, including an increase to the stock of affordable housing and emergency shelters, legislation restricting conversions and evictions, and communication and education programs directed at landlords and tenants (Ference Weicker \& Company, 2002).

\section{Subunit B: Conversion and Demolition of SRO Hotels}

Legislation attempting to restrict the conversion and demolition of SRO units was enacted in October 2003, shortly after Vancouver won the bid to host the 2010 Winter Olympic Games. The bylaw required that demolition or conversion could proceed only if a permit is applied for and approved by City council. The SRO bylaw is intended to dissuade SRO owners from renovation and demolition by the imposition of a $\$ 5,000$ levy for each room that is converted to another use (City of Vancouver, 2007a, p. 7). However, as Eby and Misura (2006) report, the intended effect of this by-law could easily be circumvented by landlords who have renovated and increased rents beyond what those on social assistance can afford, or those who leave SRO units empty rather than rent them while property values increase. Most crucially, the cost of replacing lost housing is far greater than the $\$ 5,000$ received by the City in violation of the by-law (Eby \& Misura, 2006, p. 11). In 2007 the bylaw was amended, striking the $\$ 5,000$ amount payable to the city to replace lost accommodation and raising the amount to $\$ 15,000$ (City of Vancouver, 2007a). But 
yet, as Eby (2007) reports, the city's 1-for-1 replacement policy ${ }^{11}$ for demolished or converted rooms is rarely realized. By 2007, no application to convert SRO housing was refused by City Council on the grounds of the replacement of lost housing or through the conversion of buildings that had been closed for years (Eby, 2007). Instead, statistics from Pivot Legal Society and Carnegie Community Action Project show that 1,448 units were lost since the Games were awarded in 2003 (Condon, 2009).

\section{Conclusion: Contextualizing an Olympic legacy}

The OGI Games-time report states that 'the available data, specifically for the Vancouver Olympic Village, suggest that a housing legacy (in terms of increased floor area) was established' (OGI-UBC Research Team, 2011, p. 150). Yet, as this paper has shown, by almost every other measure available, no such legacy exists. The number of units created meeting the criteria for affordable or modest market housing, the original projections for social housing units, and number of SRO units indirectly subtracted from the housing supply in the years leading up to the 2010 Winter Olympic Games all point to a vastly different outcome than the one presented by VANOC. The organizing committee's selfassessment, as reported in its final sustainability report, celebrates the Athletes' Village as 'a model sustainable community with market and affordable housing' (Vancouver Organizing Committee for the 2010 Olympic and Paralympic Games, 2010, p. 80).

The demonstrated utility of an embedded case study approach inspires us to call upon the IOC to go beyond a stated commitment to legacies and include more rigorous measures of enforcement. As we stated in an earlier paper (Pentifallo \& VanWynsberghe, 2012),

'[W]ithout mechanisms for oversight and methods for recourse in the event of unfulfilled bid pledges, Candidature Files will fail to be anything more than promises tactfully deployed as a way of attracting IOC votes....The follow-up into the post-Games period has been historically neglected, with neither the IOC nor OCOGs volunteering to report on long-term outcomes once the Olympic flame has moved on to the next host' (p. 443).

By supplementing pertinent quantitative data with a more qualitatively informed approach through embedded case study, we were able to more holistically evaluate Vancouver's social housing legacy. In doing so, we have also demonstrated that reporting on long-term outcomes well after the Games end is not only possible, but expository. By expanding our evaluation beyond square footage or social housing created and considering social housing units gained, promised, lost, and mitigated by other factors, we were able to expand what constitutes a unit of analysis and therefore expand the focus of evaluation. The admittedly brief foray into this technique has nevertheless afforded us the opportunity to combine quantitative data with the kind of contextual details necessary to evaluate impacts and legacies in context.

On a positive note for researchers and others interested in evaluating Olympic legacies and impacts, we have demonstrated how indicator-based impact assessments such as the

"The 1-for-1 replacement of SRO units is stated in the Housing Plan for the Downtown Eastside signed in September 2005. Action 3.1 states 'replace SROs with low-income social housing on a 1-for-1 basis and facilitate the integration of market housing' (Johnson \& Greenwell, 2006). 
OGI study can be used as a foundation for creating contextually rich assessments. Despite the many challenges (e.g., multiple scales, levels of analysis, and range of variables) in assessing Olympic-induced changes and the inefficiencies in the current reporting system offered by OGI, we believe it is possible to use indicator-based impact assessment to aid in the formation of a more contextualized approach to legacy assessment by adding an embedded case study method, such as this one. We have attempted to assemble an embedded case study of Vancouver 2010's social housing legacy that is sensitive to Vancouver's history, political and social climate, and urban and provincial policies governing social housing, homelessness, and urban development. Context, in this instance, is not just supplementary material, but a prerequisite for legacy assessment. It is only with the appropriate tools in hand that one can answer the larger questions that we started this paper with. These questions ask what constitutes a legacy, who defines it, and when has a legacy been achieved. These remain seminal questions that future research can seek to answer in a retrospective cross-case analysis of sport mega-event hosts. 


\section{References}

Andrews, J. (2006). Selection of a Developer for Sub-Area 2 A of Southeast False Creek Including the Olympic Village (Administrative Report). Vancouver, BC: City of Vancouver.

Ballem, P. (2011). Affordable Housing in SEFC - Update (Memorandum). Vancouver City Council.

Ballem, P., Bayne, K., \& Philpotts, T. (2009, January 9). Special Council Report: Olympic Village Project Update. PowerPoint Presentation, Vancouver, BC.

Bayne, K. (2009). Southeast False Creek Development: Financing Update (Administrative Report). Vancouver City Council.

CBC News. (2009, January 18). Vancouver gets OK to borrow to finish Olympic Village. Retrieved January 23, 2013, from http://www.cbc.ca/news/canada/britishcolumbia/story/2009/01/18/olympic-funding.html?ref=rss

City of Vancouver. (1999). Southeast False Creek Policy Statement: Toward a Sustainable Urban Neighborhood and a Major Park in Southeast False Creek. City of Vancouver, Planning Deparment.

City of Vancouver. (2002). Games Facility Agreemnet- Vancouver Athlete's Village.

City of Vancouver. (2004, 2008). Southeast False Creek Green building Strategy.

City of Vancouver. (2005). Southeast False Creek Official Development Plan.

City of Vancouver. A By-law to amend Southeast False Creek Official Development Plan by-law No. 9073, No. 9264 (2006). Retrieved from http://former.vancouver.ca/blStorage/9264.PDF

City of Vancouver. (2007a). A By-Law to Amend Single Room Accomodation By-Law No. 8733 regarding miscellaneous amendments.

City of Vancouver. (2007b). Southeast False Creek Official Development Plan.

City of Vancouver. (2012, June). Mayor's Task Force on Housing Affordability: Bold Ideas Towards an Affordable City. City of Vancouver. Retrieved from $\mathrm{ftp}: / / \mathrm{ftp} . \mathrm{cmhc}-\mathrm{schl}$.gc.ca/chicccdh/External_Reports/Ca4\%20BC\%20VANA60\%2012B53.pdf

City of Vancouver, Resort Municipality of Whistler, Canadian Olympic Committee, Canadian Paralympic Committee, \& Vancouver Bid Corporation. Multiparty Agreement for the 2010 Winter Olympic and Paralympic Games (2002). 
COHO Property Management. (2011, January). Application for Tenancy 80 and 122 Walter Hardwick Avenue, Vancouver: For Market Rent Units.

Cornelissen, S. (2009). A Delicate Balance: Major Sport Events and Development. In R. Levermore \& A. Beacom (Eds.), Sport and international development (pp. 76-97). New York: Palgrave McMillan.

Drury, I., \& Swanson, J. (2011). Upscale: The Downside of Gentrification. Vancouver, BC: Carnegie Community Action Project.

Eby, D. (2007). Still waiting at the altar: Vancouver 2010's on-again, off-again, relationship with social sustainability. In COHRE Expert Workshop on Protecting and Promoting Housing Rights in the Context of Mega Events (Vol. Geneva, Switzerland, pp. 1-17). Retrieved from http://www.cohre.org/view_page.php?page_id=269

Eby, D., \& Misura, C. (2006). Cracks in the Foundation: Solving the Housing Crisis in Canada's Poorest Neighbourhood. Pivot Legal Society.

Ference Weicker \& Company. (2002). Impact of 2010 Olympic Winter Games and Paralympic Games on Vancouver's Inner City Neighborhoods: Interim Report. Vancouver Agreement.

Gold, J., \& Gold, M. (2009). Future indefinite? London 2012, the spectre of retrenchment and the challenge of Olympic sports legacy. The London Journal, 34(2), 179-196.

Gray, C., \& Smith, I. (2009). The Cost and Affordability of the City's Affordable Housing: Southeast False Creek Area 2 A (Olympic Village) (Administrative Report). Vancouver City Council.

Heartly, J. (2004). Case study research. In Essential Guide to Qualitative Methods in Organizational Research (pp. 323-333). Thousand Oaks: SAGE Publications.

Housing Justice Project. (2012, October 9). Vancouver, Canada: A study in Housing Injustice. Submission to Officia of the High Commissioner for human Rights. Retrieved from http://housingjustice.ca/wp-content/uploads/2013/02/HousingJustice-Submission-UPR-CANADA.pdf

International Olympic Committee. (2004, September 1). Olympic Charter. International Olympic Committee.

International Olympic Committee. (2006). Focus: What is the Olympic Games Global Impact Study? International Olympic Committee. Retrieved from http://www.olympic.org/Documents/Reports/EN/en_report_1077.pdf

International Olympic Committee. (2007). Technical Manual on Olympic Games Impact. International Olympic Committee. 
International Olympic Committee. (2012). Factsheet: The Environment and Sustainable Development. International Olympic Committee.

Johnson, B., \& Greenwell, P. (2006). Downtown Eastside Housing Plan - Report Back on SRO Stock (Administrative Report No. RTS. 05512). Vancouver, BC: City of Vancouver.

Kines, L., \& Bermingham, J. (2009, January 17). Vancouver's Olympic bailout bill passes. Retrieved from http://www.nationalpost.com/news/story.html?id=1191361

Lee, E. (2008). City of Vancouver 2007 Statement of Financial Information (Administrative Report No. RTS. 07179). Vancouver, BC: City of Vancouver.

OGI-UBC Research Team. (2011). Olympic Games Impact (OGI) Study for the 2010 Olympic and Paralympic Winter Games: Games-time Report. Vancouver, BC: University of British Columbia.

Olds, K. (1988). Planning for the Housing Impacts of a Hallmark event: A case study of Expo 86. University of British Columbia, Vancouver, BC. Retrieved from https://circle.ubc.ca/bitstream/handle/2429/28192/UBC_1988_A8\%20042.pdf?se quence $=1$

Olds, K. (1998). Urban mega-events, evictions and housing rights: The Canadian case. Current Issues in Tourism, 1(1), 2-46.

Pentifallo, C., \& VanWynsberghe, R. (2012). Blame it on Rio: isomorphism, environmental protection and sustainability in the Olympic Movement. International Journal of Sport Policy and Politics, 4(3), 427-446. doi:10.1080/19406940.2012.694115

Raynor, P., \& Johnson, B. (2007). 2007 Survery of Low-income Housing in the Downtown Core (Administrative Report No. RTS. 06589). Vancouver, BC: City of Vancouver.

Ritchie, J. R. B. (1984). Assessing the Impact of Hallmark Events: Conceptual and Research Issues. Journal of Travel Research, 23(1), 2-11. doi:10.1177/004728758402300101

Rogers, J. (2002). 2010 Olympic Winter Games and Paralympic Winter Games Bid: Status Report (No. RTS. No. 02869).

Scholz, R. W. (2002). Embedded Case Study Methods: Integrating Quantitative and Qualitative Knowledge. SAGE.

Scholz, R. W., \& Tietje, O. (2002). Types of Case Studies. In R. W. Scholz \& O. Tietje (Eds.), Embedded Case Study Mehtods (pp. 9-15). Thousand Oaks: SAGE. 
Statistics Canada. (2013, October 2). Median total income, by family type, by census metropolitan area. Retrieved November 28, 2013, from

http://www.statcan.gc.ca/tables-tableaux/sum-som/101/cst01/famil107a-eng.htm

Vancouver Bid Corporation. (2002a). Vancouver 2010 Applicant City Responses. Vancouver Whistler 2010 Bid Corporation.

Vancouver Bid Corporation. (2002b). Vancouver 2010 Candidate City. Vancouver Whistler 2010 Bid Corporation.

Vancouver Organizing Committee for the 2010 Olympic and Paralympic Games. (2010, September). Staging the Olympic Winter Games Knowledge Report. VANOC.

VanWynsberghe, R. (2014). The Olympic Games Impact (OGI) study for the 2010 Winter Olympic Games: Strategies for evaluating sport mega-events' contribution to sustainability. International Journal of Sport Policy and Politics. doi:10.1080/19406940.2013.85212

VanWynsberghe, R., \& Kahn, S. (2007). Redefining Case Study. International Journal of Qualitative Methods, 6(2), 80-94.

Yin, R. K. (2009). Case study research: design and methods. Los Angeles, Calif.: Sage Publications. 